\title{
A NEW SPECIES OF LORRYIA (ACARI: TYDEIDAE) FROM A TERMITE NEST IN SOUTH AFRICA
}

\author{
Alexander A. Khaustov ${ }^{1^{*}}$, Elizabeth A. Hugo-Coetzee ${ }^{2,3}$ and Sergey G. Ermilov ${ }^{1}$
}

\author{
${ }^{1} \mathrm{X}$-BIO Institute, Tyumen State University, Tyumen, Russia \\ ${ }^{2}$ Terrestrial Invertebrate Department, National Museum, Bloemfontein, South Africa \\ ${ }^{3}$ Department of Zoology and Entomology, University of the Free State, Bloemfontein, South Africa \\ "corresponding author; e-mail: alex1973khaustov@gmail.com
}

\begin{abstract}
A new species-Lorryia pseudoplacita sp.n.-is described from central South Africa. It was collected from a nest of the termite Trinervitermes trinervoides (Sjöstedt, 1911) (Isoptera: Termitidae). The new species differs from $L$. placita in the shape of the dorsal setae and in having a shorter palptarsus.
\end{abstract}

KEY WORDS: Tydeoidea, systematics, morphology, SEM microscopy, Ethiopian region.

DOI: 10.21684/0132-8077-2020-28-1-47-53

\section{INTRODUCTION}

The family Tydeidae currently includes more than 300 species, sorted into about 30 genera; it is a diverse group of mostly fungivorous mites, characterized by a worldwide distribution (Silva et al. 2016; Kaźmierski et al. 2018). Twenty-one species of Tydeidae have been described from South Africa: Pretydeus curiosa (Ueckermann and Smith Meyer, 1979), Ueckermannia grewiae (Ueckermann, 1988), Lorryia celtides Ueckermann and Smith Meyer, 1979, L. furcata (Ueckermann and Smith Meyer, 1979), L. leonorae (Ueckermann and Smith Meyer, 1979), L. monticola (Ueckermann and Smith Meyer, 1979), L. ponglana Ueckermann and Smith Meyer, 1979, L. pseudovaritas (Theron and Ueckermann, 2012), L. relhaniae Ueckermann and Smith Meyer, 1979, L. rutrus (Theron and Ueckermann, 2012), L. varitas (Theron and Ueckermann, 2012), L. vinea (Ueckermann and Smith Meyer, 1979), L. zebramontana (Smith Meyer, 1988), Nudilorryia schotiae (Ueckermann, 1988), Orfareptydeus stepheni Ueckermann and Grout, 2007, Pseudolorryia andreae (Ueckermann and Smith Meyer, 1979), P. fustis (Ueckermann, 1988), P. pseudofustis (Theron and Ueckermann, 2012), Tydeus africanus Baker, 1970, T. munsteri Meyer and Ryke, 1959 and T. reticoxus (Ueckermann, 1988) (Ueckermann and Smith Meyer 1979a, b; Smith Meyer and Ueckermann 1988; Ueckermann and Smith Meyer 1988; Theron et al. 2012; Silva et al. 2016). The genus Lorryia Oudemans, 1925 sensu Kaźmierski, 1989 is the largest in the family and includes two thirds of all known tydeid mites (Silva et al. 2016).

Previously, we have described many new taxa of prostigmatic and oribatid mites from termite nests in South Africa (Ermilov et al. 2017a-c, 2019;
Khaustov et al. 2017a, b, 2018a, b, 2019a, b). During the study of mites inhabiting termite nests in South Africa, a new species of Lorryia was discovered in the nest of Trinervitermes trinervoides (Sjöstedt, 1911) (Isoptera: Termitidae). The aim of this paper is to describe the new species and to compare it with the holotype of the closely related L. placita (Livshitz, 1973).

\section{MATERIALS AND METHODS}

The mites were collected from termite nests with shovels and extracted using Berlese funnels. Most of the mites were mounted in Hoyer's medium. For SEM microscopy, several alcohol-preserved mites were dried in a JFD 320 (JEOL, Japan) freeze-drying device, coated with gold and scanned with a TESCAN Mira3 LMU SEM microscope. The mite morphology was studied using a Carl Zeiss AxioImager A2 compound microscope with phase contrast and DIC illumination. Notations applied to the body and leg setae follow the system of Grandjean - overviewed by Kethley (1990) and André (1981b), respectively - with minor modifications. The palpal setation follows André (1981a). The systematics of Tydeidae follows Kaźmierski (1998). The photomicrographs were taken with an AxioCam ICc5 digital camera. All the measurements are given in micrometers $(\mu \mathrm{m})$ for the holotype and for the five paratypes (in parentheses).

\section{SYSTEMATICS}

Family Tydeidae Kramer, 1877

Genus Lorryia Oudemans, 1925 sensu

Kaźmierski, 1989

Type species: Lorryia superba Oudemans, 1925 , by original designation. 

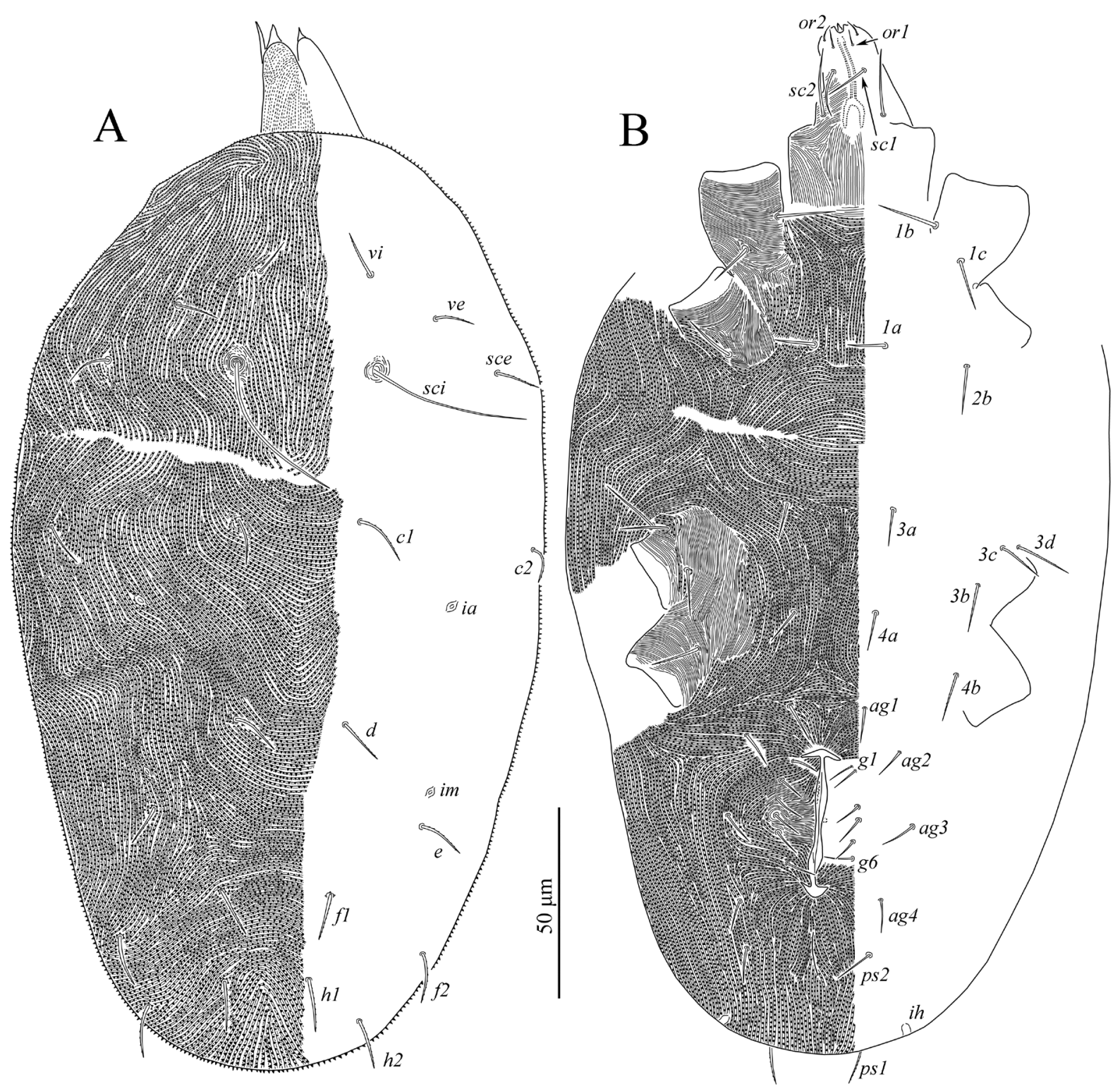

Fig. 1. Lorryia pseudoplacita sp.n., female: A—dorsum of the body, B — venter of the body. Legs omitted.

\section{Lorryia pseudoplacita sp.n.}

(Figs. 1-5)

Description. With character states described for the genus Lorryia in Kaźmierski (1989). Female. Body ovate, yellowish in living mites. Length of idiosoma 270 (260-270), maximum width 150 (150-165).

Idiosomal dorsum (Figs. 1A, 4A). Dorsal ornamentation: striation type "Tydeus"; dorsal stria with tubercles (Fig. 4A); no reticulation patterns on idiosoma; more than 20 stria lie between trichobothria. Trichobothria smooth, whip-like, about three times longer than other prodorsal setae; other dorsal setae subequal in length and shape, thin, slightly curved and weakly barbed (Fig. 4A). Lengths of setae: $v i$
10 (10-12), ve 12 (10-12), sci 44 (34-44), sce 13 (12-14), cl 14(13-15), c2 11 (13-15), d 12 (12-15), e 14 (13-16), fl 14 (14-15), f2 13 (13-15), hl 13 (12-14), h2 14 (12-16), psl 12 (11-14).

Idiosomal venter (Figs. 1B, 5A, B). Cuticular tubercles on ventral stria in general smaller than on dorsal surface; stria between setae $3 a$ and $4 a$ longitudinal (Fig. 5A). Lyrifissures $i h$ situated near posterior edge of opisthosoma. Coxal organs very small, ovate. Epimeral formula 3-1-4-2. Six pairs of genital and four pairs of aggenital setae (Fig. $5 \mathrm{~B}$ ); some specimens with asymmetric number of genital setae $5 / 6,5 / 7$ or $6 / 7$.

Gnathosoma (Figs. 2, 4B, C). Gnathosoma not covered by idiosoma. Cheliceral stylets 17 (17-18) longer than palptarsus 12 (12-13) and slightly 

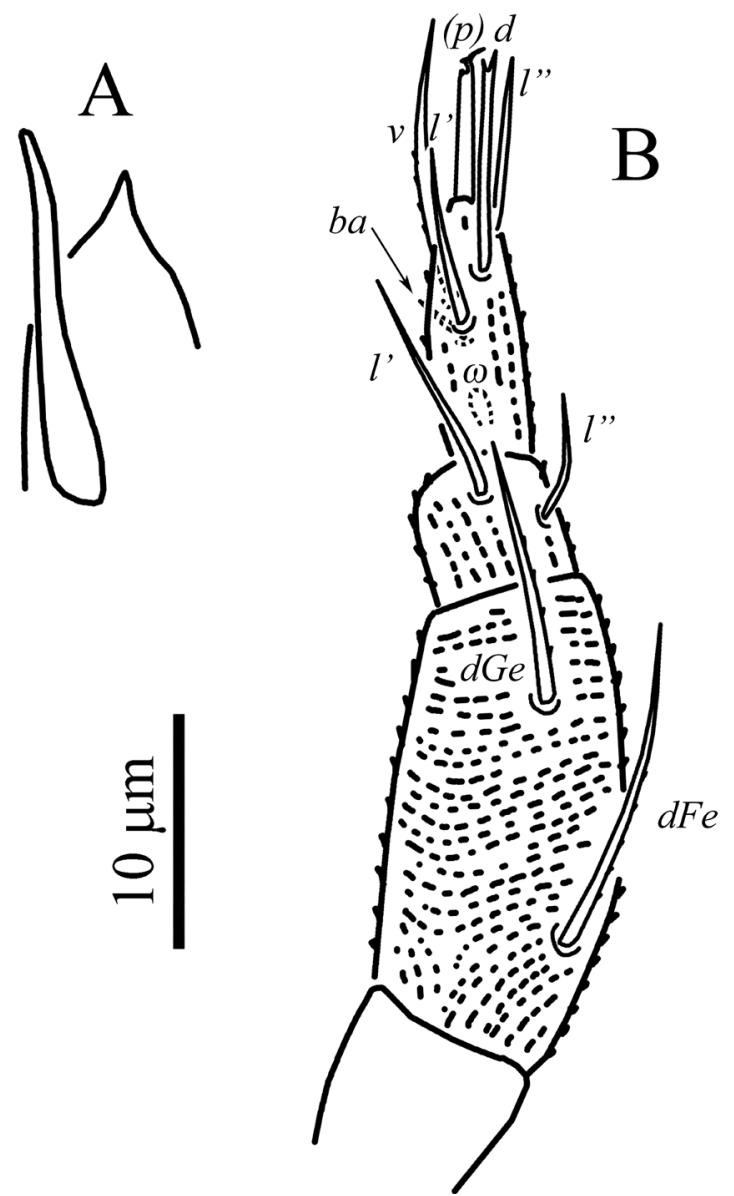

Fig. 2. Lorryia pseudoplacita sp.n., female: A—cheliceral stylet, B—palp, dorsal aspect.

shorter than combined length of palptarsus and eupathidiun ( $p$ ) 20 (19-20). Palpal organotaxy: $0-2-2-6+\omega$. Palpal terminal eupathidium with Tshaped projection distally; seta $d$ bifurcate distally.

Legs (Figs. 3, 4D, 5C, D). Legs setation typical for the genus. Setae $(p),(t c)$ and $f t$ " of tarsus I eupathid-like, smooth, other setae on legs thin and weakly barbed. Solenidion $\omega$ (7) on tarsus I fingershaped (Fig. 5C); solenidion $\omega$ (3) on tarsus II rod-like (Fig. 5D). Famulus $k$ on tibia I multibranched distally (Fig. 4D). Empodia with very small empodial hooks.

Male similar to female, differing only in having a longitudinal slit-like genital opening and four pairs of short and barbed eugenital setae.

Larva, protonymph, deutonymph and tritonymph unknown.

Type material. Female holotype, slide AK221018/T, South Africa, Bloemfontein, Franklin Game Reserve on Naval Hill, $29^{\circ} 05^{\prime} 57.9^{\prime \prime} \mathrm{S}$ $026^{\circ} 14^{\prime} 03.2^{\prime \prime} \mathrm{E}, 1,404 \mathrm{~m}$ a.s.1., in the nests of termites Trinervitermes trinervoides, 22 October 2018, collected by A.A. Khaustov, S.G. Ermilov and E.A. Hugo-Coetzee; paratypes: 9 females, 7 males, same data.
Type deposition: the holotype, four female and two male paratypes are deposited in the acarological collection of the National Museum, Bloemfontein, South Africa (NMBS); other paratypes are deposited in the mite collection of the Tyumen State University Museum of Zoology, Tyumen, Russia (TSUMZ).

Etymology. The name of the new species is a combination of the Greek pseudo, meaning false, and the Latin placita - the species epithet of the closely related species, $L$. placita.

Differential diagnosis. The new species is very similar to L. placita, described from Crimea (Kuznetsov and Livshitz 1973) in having a similar type of striation and dorsal body setae. We examined the holotype of L. placita, housed in TSUMZ, and found the shapes of the dorsal body setae to be slightly different in the two species. In fact, in L. placita, setae vi, ve, sce and $c 2$ are clearly thinner and weaker barbed (Fig. 6B) than other dorsal hysterosomal setae (Fig. 6A). In L. pseudoplacita, on the other hand, all dorsal setae are uniformly thin and weakly barbed. The new species also differs from $L$. placita in having a distinctly shorter palptarsus (12-13 vs. 19 in L. placita). 

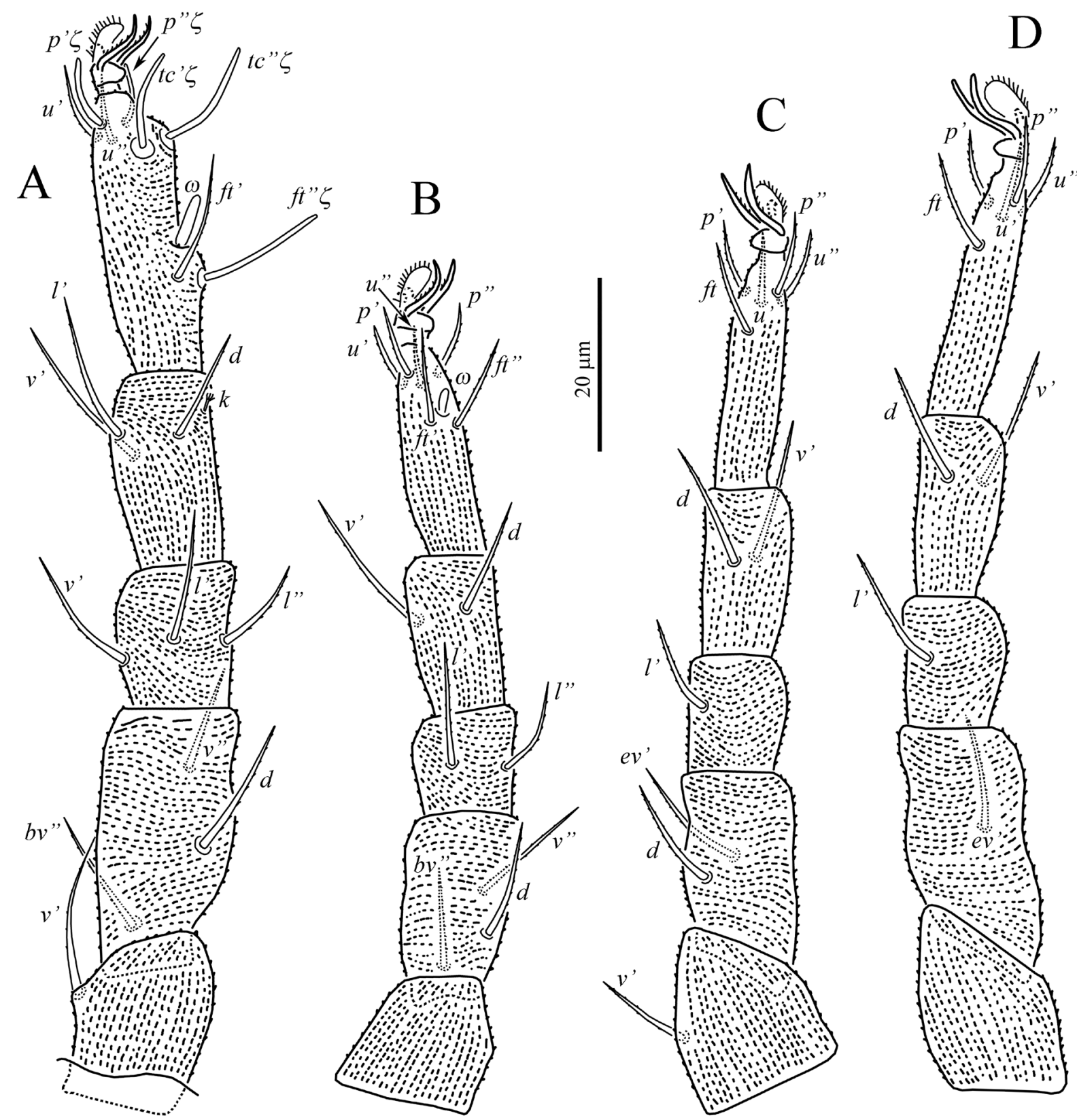

Fig 3. Lorryia pseudoplacita sp.n., female: A-D—legs I-IV, dorsal aspect.

Remarks. Tydeid mites have never been recorded in termite nests.

\section{ACKNOWLEDGEMENTS}

The authors thank Dr. N.V. Beljaeva (Moscow State University, Moscow, Russia) for the identification of the termite species and A.N. Bobylev (Tyumen State University, Russia) for the SEM images.

The study was supported by the Russian Foundation for Basic Research (RFBR), the research project No. 18-04-00096A.

\section{REFERENCES}

André, H.M. 1981a. A generic revision of the family Tydeidae (Acari: Prostigmata). II. Organotaxy of the idiosoma and gnathosoma. Acarologia, 22: 31-40.

André, H.M. 1981b. A generic revision of the family Tydeidae (Acari: Prostigmata). III. Organotaxy of the legs. Acarologia, 22: 165-178.

Ermilov, S.G., Hugo-Coetzee, E. A. and Khaustov, A.A. 2017a. Coetzeella navalensis gen. nov., sp. nov. (Acari, Oribatida, Oppiidae) from South Africa. Systematic and Applied Acarology, 22 (3): 403-409.

Ermilov, S.G., Hugo-Coetzee, E. A. and Khaustov, A. A. 2017b. Oribatid mites (Acari, Oribatida) 


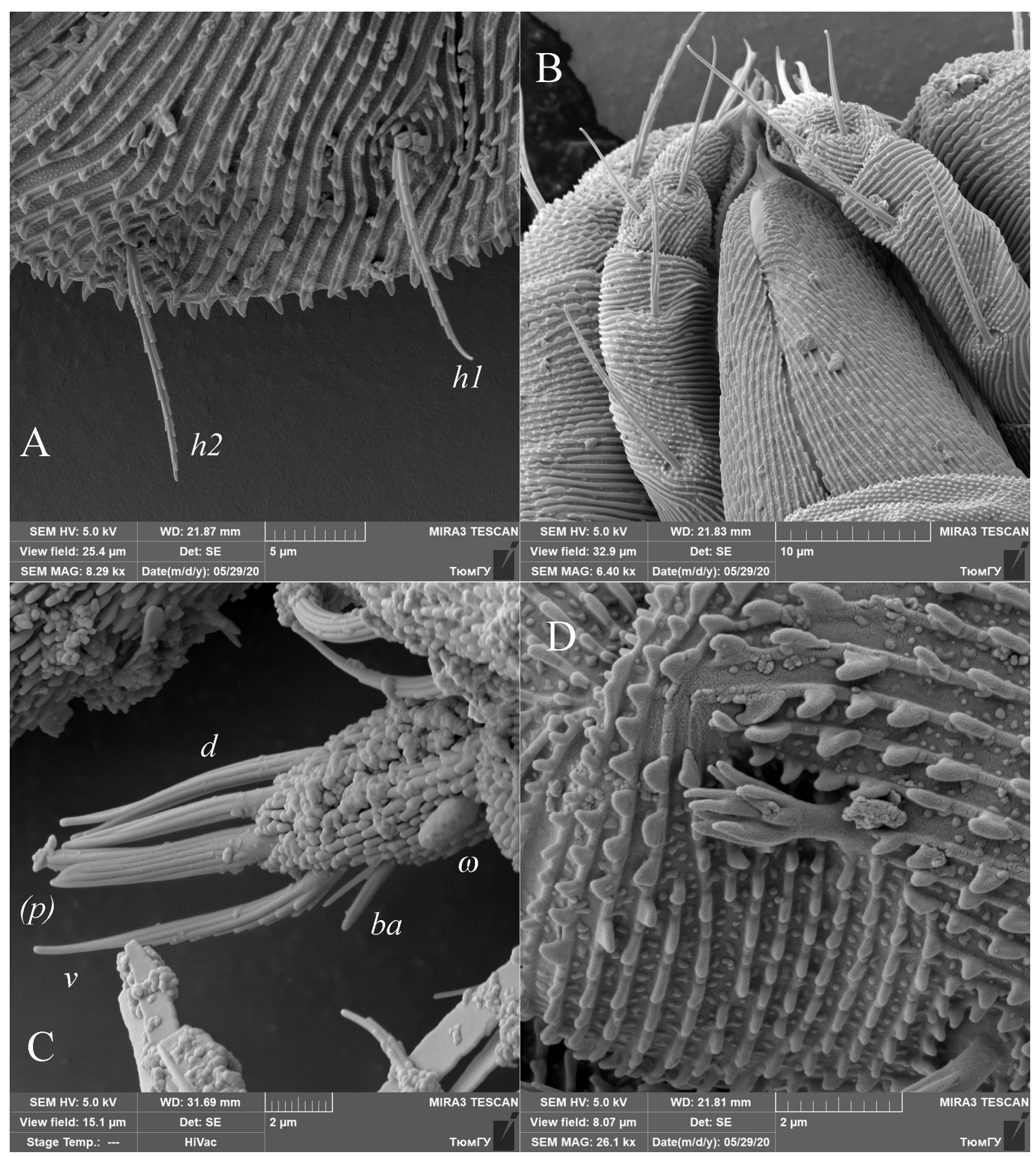

Fig. 4. SEM micrographs of Lorryia pseudoplacita sp.n., female: A-left posterior opisthosomal part with setae $h 1$ and $h 2, \mathrm{~B}$ - gnathosoma, dorsal aspect, $\mathrm{C}$ - palptarsus, ventral aspect, D—famulus $k$ on tibia I.

inhabiting nests of the termite Trinervitermes trinervoides (Sjöstedt) in the Franklin Game Reserve (Bloemfontein, South Africa), with description of a new species of the genus Ceratobates (Tegoribatidae). Systematic and Applied Acarology, 22(10): 1715-1732.

Ermilov, S.G., Hugo-Coetzee, E. A. and Khaustov, A. A. 2017c. Two new species of the genus Ausoribula (Acari, Oribatida, Oribatulidae) from termitaries of South Africa. Acarologia, 57(3): 643-650.
Ermilov, S.G., Hugo-Coetzee, E.A., Khaustov, A.A. and Theron, P.D. 2019. Oribatid mites (Acari, Oribatida) inhabiting termite nests in the Faan Meintjes Nature Reserve (South Africa). Systematic and Applied Acarology, 24: 783-1798.

Kaźmierski, A. 1989. Revision of the genera Tydeus Koch sensu André, Homeotydeus André and Orthotydeus André with description of a new genus and four new species of Tydeinae (Acari: Actinedida: Tydeidae). Mitteilungen Hamburgisches Zoologisches Museum und Institut, 86: 289-314. 


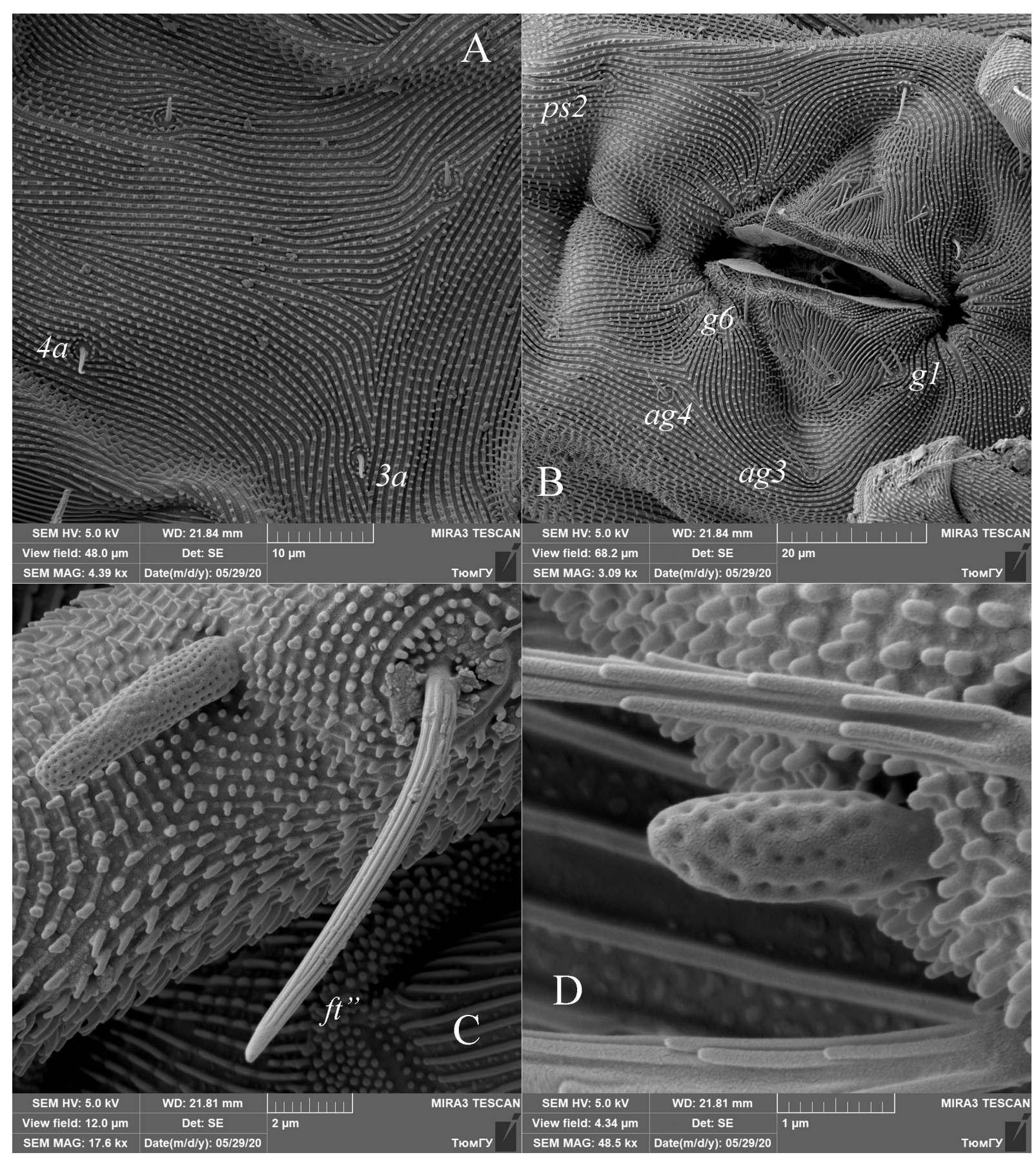

Fig. 5. SEM micrographs of Lorryia pseudoplacita sp.n., female: A-type of striation between metasternal setae, $\mathrm{B}$ - ano-genital area, C—solenidion and eupathidium $f t$ ” on tarsus I, D—solenidion on tarsus II.

Kaźmierski, A. 1998. Tydeinae of the world: generic relationships, new and redescribed taxa and keys to all species. A revision of the subfamilies Pretydeinae and Tydeinae (Acari: Actinedida: Tydeidae)part IV. Acta Zoologica Cracoviensia, 41: 283-455.

Kaźmierski, A., Marciniak, M. and Sikora, B. 2018. Tydeinae mites (Acariformes: Prostigmata: Tydeidae) from bird nests with description of three new species. Systematic and Applied Acarology, 23: 803-823.
Kethley, J. 1990. Acarina: Prostigmata (Actinedida). In: D.L. Dindal (Ed.). Soil Biology Guide. John Wiley and Sons, New York, pp. 667-753.

Khaustov, A. A., Hugo-Coetzee, E. A. and Ermilov, S.G. 2017a. A new genus of the mite family Scutacaridae (Acari: Heterostigmata) associated with Trinervitermes trinervoides (Isoptera: Termitidae) from South Africa. Zootaxa, 4258(5): 462-476.

Khaustov, A. A., Hugo-Coetzee, E.A. and Ermilov, S. G. 2017b. A new genus and two new species of Pyg- 


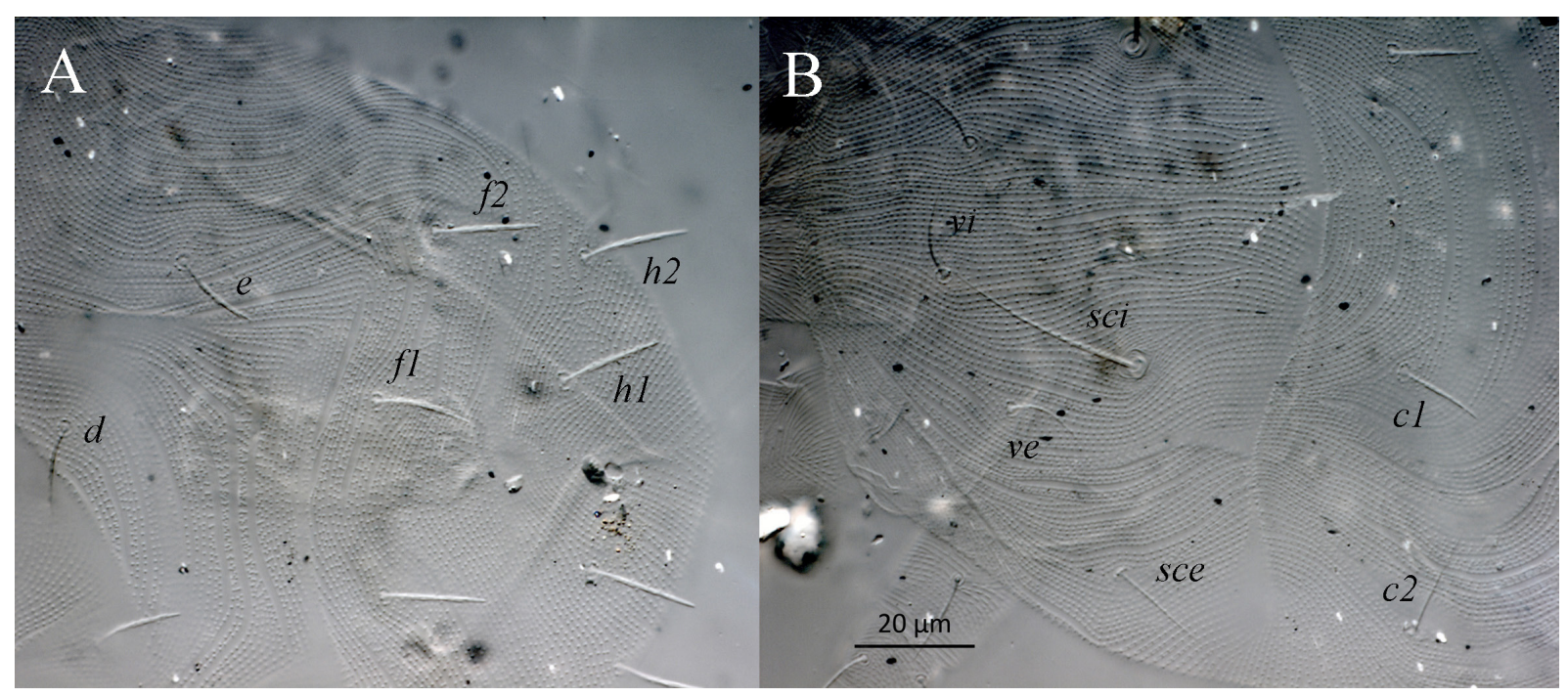

Fig. 6. DIC micrographs of Lorryia placita (Livshitz, 1973), female (holotype): A—hysterosomal dorsum, B—prodorsum and anterior part of hysterosoma.

mephoridae (Acari: Heterostigmata) associated with Trinervitermes trinervoides (Isoptera: Termitidae) from South Africa. Zootaxa, 4258(5): 462-476.

Khaustov, A. A., Hugo-Coetzee, E. A. and Ermilov S. G. 2018a. A new species of Scutacarus (Acari: Heterostigmata: Scutacaridae) associated with Trinervitermes trinervoides (Isoptera: Termitidae) from South Africa. International Journal of Acarology, 44: 59-67.

Khaustov, A. A., Hugo-Coetzee, E. A. and Ermilov S.G. 2018b. New taxa of the family Microdispidae (Acari: Heterostigmata) associated with Trinervitermes trinervoides (Sjostedt) (Isoptera: Termitidae) from South Africa. International Journal of Acarology, 44: 218-226.

Khaustov, A.A., Hugo-Coetzee, E. A. and Ermilov, S.G. 2019a. A new genus, new species and a new record of the family Pygmephoridae (Acari: Heterostigmata) associated with Microcerotermes parvus (Haviland) (Isoptera: Termitidae) from South Africa. Systematic and Applied Acarology, 24: 1881-1892.

Khaustov, A. A., Hugo-Coetzee, E. A. and Ermilov, S. G. 2019b. A new species of Tanytydeus (Acari: Paratydeidae) from termite nests in South Africa. Systematic and Applied Acarology, 24: 1604-1619.
Kuznetzov, N.N. and Livshitz, I.Z. 1973. [Genus Tydeus (Acariformes, Tydeidae) in materials from Crimea and Caucasus]. Zoologicheskii Zhurnal, 52: 45-53. (In Russian)

Silva, G.L., Metzelthin, M.H., Silva, O.S. and Ferla, N.J. 2016. Catalogue of the mite family Tydeidae (Acari: Prostigmata) with the world key to the species. Zootaxa, 4135(1): 1-068.

Smith Meyer, M.K.P. and Ueckermann, E.A. 1988. South African Acari. III. On the mites of the Mountain Zebra National Park. Koedoe, 31: 1-29.

Theron, N., Roets, F., Dreyer, L.L., Esler, K.J. and Ueckermann, E.A. 2012. A new genus and eight new species of Tydeoidea (Acari: Trombidiformes) from Protea species in South Africa. International Journal of Acarology, 38: 257-273.

Ueckermann, E.A. and Smith Meyer, M.K.P. 1979a. African Tydeidae (Acari). I. The genus Lorryia Oudemans, 1925. Phytophylactica, 11: 43-50.

Ueckermann, E.A. and Smith Meyer, M.K.P. 1979b. African Tydeidae (Acari). II. The genus Paralorryia Baker 1965. Phytophylactica, 11: 117-127.

Ueckermann, E.A. and Smith Meyer, M.K.P. 1988. South African Acari. IV. Some mites of the Addo Elephant National Park. Koedoe, 31: 31-51. 